QIJIS: Qudus International Journal of Islamic Studies

Volume 7, Number 2, 2019

DOI : $10.21043 / q i j i s . v 7 i 2.6449$

\title{
HOLISTIC-INTEGRATIVE EDUCATION SYSTEM IN AN ISLAMIC KINDERGARTEN
}

\author{
Fauzi \\ IAIN Purwokerto \\ fauzi@iainpurwokerto.ac.id \\ Supa'at \\ IAIN Kudus \\ supaatkudus@yahoo.com \\ Ifada Novikasari \\ IAIN Purwokerto \\ ifa_da@iainpurwokerto.ac.id
}

\begin{abstract}
This research aims at examining the holisticintegrative approach system model appliedto an Islamic Kindergarten in Purwokerto city, Banyumas Regency. This qualitative research employs acase study with observation, interview and documentation as the data collection techniques. The data are then analyzed using two analysis techniques, namely content analysis and comparative analysis, with an interactive cycle. Based on the findings, the education developed through thesystematic approach ranges from the input resourcesstrengthening process, processes and transformation of raw inputs involving process quality elements, setting output targets with clear and measurable characteristics, and orientation to education unit users. The Islamic Kindergarten's system is formulated in an integrated holistic system format model of early childhood education (sources,
\end{abstract}


environment, process, transformation, output, and user). The model is developed by the researcher out of Kaufman's model and Smith's modelfor general system approach model.

Keywords: Education system, early childhood education, holistic-integrative.

\section{A. Introduction}

The implementation of national movement for early childhood education (Pendidikan Anak Usia Dini- PAUD) or known as the Paudisasi movement is expected to increase the number of quality PAUD sthroughout Indonesia. As set forth in Presidential Regulation No. 60 of 2013, PAUD sneed to provide good education and services to form quality young generation. Such quality education is expectedly felt throughout Indonesia evenly. In fact, however, PAUD's 2019 gross participation rate (APK) for 3-4 year-old children still shows that $34 \%$ children are not going to PAUD (Nengsi, 2019). Based on the result, the APK of early children registered as PAUD students in Indonesia is very low and the awareness of the importance of PAUD has not developed well. The low APK is still accompanied with the challenges faced by PAUD, such as low quality of care, parental and educator intervention program at early childhood and low number of early childhood (Saipudin, 2010).

The explanation above clearly shows the gap between the increasing quantity and expansion of access to PAUD's services, also the high public demand for PAUD, and the quality of services for children's growth and development supposedly provided by PAUD institutions. The rapid development of early 
childhood institutions and the community's high demand must be admitted not to be in line yet with the improvement of service quality needed by children as stipulated in early childhood education standards (Permendikbud, 2014).

Various challenges are still faced in the Paudisasi movement in Indonesia from the perspectives of APK and low quality. Referring to Janta, van Belle, and Stewart (2016) that for PAUD to have a good quality, PAUD needs to have safe and healthy environment and prepare children for their transition to the next phase of school and to have positive social and academic development. according to Regulation of the Ministry of Education No 58 of 2009 set out norms of PAUD service development using a holistic integrative approach, children's whole needs are more than merely academic needs (PERMENDIKNAS, 2009).

The low quality of existing PAUDs, as explained above, may be caused by the absence of reliable references or formulas eligible to be used as practical-applicative references for the implementation of early childhood education in the community (Pianta, Downer, \& Hamre, 2016). In this regards, it is important to reformulate the format of early childhood education system originating from the spirit of locality (bottom-up formulation) that is practical-applicative to be reference for the development of PAUD institutions as the center of development of children's various potentials in a holistic and integrative manner.

The efforts to formulate a holistic-integrative early childhood education system format may be performed by formulating an education system developed by system education at school. Janta, van Belle, and Stewart (2016) 
describe a system approach for a quality PAUD, which is PAUD with safe and healthy environment, may prepare children for their transition to the next phase of school and to have positive social and academic development. This is made by improving the orientation quality and structure quality through interaction between educational professionals and children (parents, colleagues, etc.). The concerned orientation quality means pedagogues as children and parents' goal, value and attitude. The goal and value of education are directly influenced by pedagogic quality. It is leader's duty to 'translate' the goal and value of education into a pedagogic concept, to be created and reflected by team, parents and other stakeholders involved in the educational process.

The effort to improve the quality above is also performed at kindergarten. Based on Law of National Educational System No. 20/2003 number 1 clause 14, kindergarten (TK) is part of PAUD for children before they enter elementary schools, one of which is an Islamic Kindergarten in Purwokerto city, Central Java named TK Al-Irsyad Purwokerto. TK Al-Irsyad has attempted to apply the holistic-integrative system approach simultaneously, systematically, thoroughly, integrated and continuously in accordance with Presidential Regulation No.60 of 2013. It is interesting to study how the development model is applied at TK Al-Irsyad Purwokerto, since the TK is a pilot TK in Purwokerto.

\section{B. PAUD Development Model}

As the effort to apply a development model to PAUD, numerous studies on early childhood education models have previously been conducted by researchers and scientists who 
are concerned about the existence of PAUD. Dodge, Colker, and Heroman (2010) offer a model of structuring early childhood education's (physical) environment with a concept of area division, called as the areas of interest. There are eight areas of children's interest that need to be designed in PAUD learning environment, namely blocks area, house corner, table toys, art area, sand and water area, library area, music and movement area, and outdoor play area.

The proper educational concept in accordance with children's developmental stages has been carried out by several PAUD experts, including Bredekamp \& Copple (2009) and Gestwicki (2013). Based on the concept, PAUD educators must understand that each of children has unique different talents, interests, strengths, weaknesses, and experiences. Therefore, the education provided should be pursuant to child's uniqueness. The concept of that approach has become a reference in the implementation of early childhood education programs in Indonesia.

Furthermore, a number of studies have been conducted by Indonesian experts, including those on various basic principles and learning models of PAUD by Suyanto. In his study, Suyanto (2005) focuses more on the discourse of educative interaction process in learning activities, instead of on the discourse of PAUD education as a system. Meanwhile, Patmonodewo examines institution models for pre-school children. In his study, Patmonodewo (2003) offers the concept of pre-school education models, which, among others ,refer to and are originated from: Montessori model; the behavioral model of Watson, Thorn, and Skinner; and the high/scope model conceived by Weikart. Yus (2011) describes PAUD 
models conceptually conceived and developed by PAUD experts and PAUD models in several countries. The study also features a description of how to implement the PAUD model in learning. The studies on PAUD model shave their own peculiarities.

With a development model which uses a system approach, it is to study PAUD development from the perspective of supporting elements and expected PAUD results. Such system approach is performed since it may design an organizational model comprehensively (Tunas, 2007). An example of this model is Smith's system model. Smith provides other alternative in a system approach model for organization and management, in this case all important parameters of a system are explained. The parameters include: source, input, transformation process, output, receiver utilities, and feedback. This Smith's model will make it easier for us to understand and identify any components and factors related to the organizational system we are observing(Tunas, 2007). This research will study the PAUD organizational system of TK Al Irsyad. TK Al Irsyad is chosen since this TK serves as a pilot TK located at the center of Purwokerto city. The system approach of TK Al Irsyad is chosen to explore the organizational approach used.

\section{Research Method}

This qualitative research employs a case study, since this research will analyze the PAUD development model of TK AL Irsyad, Purwokerto (Moleong, 2017). This research is conducted in depth, process-oriented, and based on the assumption of dynamic reality (Faisal, 1989). The data are collected through interview, observation, and documentation techniques. 
The research subjects for interview are the principal, teachers, students' guardians, and students. This school has 11 teachers, 4 teachers of which have teacher training educational background ( 2 teachers with early childhood educational background) and 7 teachers have not teacher training educational background. All of the teachers are female and have averagely 6 years of teaching experience and have taken PAUD management training. The interview with the principal is conducted to collect the management, activities/ programs, student recruitment, teachers' competency development, cooperation networks, and institution quality improvement data. Meanwhile, the interviews with teachers focus more on collecting the data of learning activities starting from preparation, implementation, to assessment of children's development to collect the data of creative efforts undertaken to improve learning quality. The interviews with students' guardians are conducted to collect data related to their reason of sending their children to this kindergarten, their perception of this kindergarten, as well as to collect information of children's development after entering and studying in this kindergarten. In addition, the interviews with the students are directed to explore information about their experiences, in which they find it fun and impressive to participate in the learning activities in this kindergarten.

An observation is carried out to obtain the data of the arrangement of school setting and learning spaces, the situation and learning climate, the learning process as the application of the learning model chosen by the kindergarten. The observation is conducted directly to find out the kindergartens situation and condition, teacher and students' 
activities from students' arrival until they go home. The daily activities with in a week are also a point of focus in the observation process, as well as the educational play tools and learning resources owned by the school and their utilization.

A documentation technique is employed to collect the data of kindergartens profile, its development over time, students' background, and their achievements. Documents taken as the sources of data are school's profile book, student's database, certificates, trophies, student progress report, curriculum, semester program, weekly activity plan (RKM), and daily activity plan (RKH).

Two analyses are conducted to analyze the collected data, namely content analysis and comparative analysis. The data processing and analyzing are conducted in an interactive, rotating and repeated cycle, but not bound to stages. Thus, more data may be recollected after an interpretation is made, when the data are considered insufficient. In that manner, the data collecting and analyzing process may run simultaneously, however, the collected data are tentative (Mayring, 2014). After completing the analysis, the subsequent activity is to make a conclusion in the form of formulating the study final results in response to the research problem as well as the expected outcome of achieving the research objectives.

\section{Findings and Discussion}

The learning model applied at TK Al-Irsyad Al-Islamiyah Purwokerto is a combination of center and area models with Montessori method through class movement method. The center model includes block center, role-playing, imtaq, music, natural materials, preparation, art/creativity, cookery, and 
outdoor educational games tools. The programs implemented in the kindergarten encourage students' activeness to be free and creative in the center model integrated in learning activities as presented in the research conducted by Shoval, Sharir, Arnon, and Tenenbaum (2018). The research shows that among the three interventions of (1) a mindful movement, integrates activeness in academic learning; (2) a movement for its own sake, gives students freedom to be active without giving any academic instructions, and (3) a control condition, students are engaged in regular academic environment activities, the one to increase children's academic success to the highest degree is the first intervention. The mindful movement intervention" is applied at TK Al Irsyad in the form of center and area models.

The approach system employed at TK AL Irsyad to develop a quality religious based school model is to consider input, process, output and user. Similarly to Smith's system model, organizational system employs the parameters: source, input, output, transformation process, output, receiver utilities, and feedback (Tunas, 2007).

Are obtained in consideration of input sources that TK AL Irsyad considers teachers and educational staff. According to Fonsén \& Soukainen (2019), the pedagogical leadership component is an important factor for teachers with professional qualification to develop early childhood education. The general principles underlying TK AlIrsyadentire education service system are oriented to a service excellence system. The principles of service excellence include comprehensive and integrated service system in various aspects needed for early childhood growth, based 
on and referred to various government regulations related to PAUD, fulfillment of human resources'positions (teachers and staff) and their quality enhancement, creative curricula developmentto meet children's needs, adequate funding by promoting transparency and accountability, structuring the environment and learning infrastructure that enable children to play safely, comfortably, and pleasantly, networking with various parties to strengthen the ongoing education system.

TK Al-Irsyad orients its learning activities to values cultivation and students' character building based Islamic values. All learning activities are directed to build children noble, independent, creative, responsible, resilient, and tough characters. This TK bases every activity on Islamic teaching since Islam may provide good human being in education (Alhamuddin, 2018) by developing the focus on children social skill and preparing them for further education. According to (Demina, Effendi, Ananda, \& Damansyah, 2019) Islamic education in schools can provide spiritual strength, self-control, and a variety of life skills that are useful for individuals, the society, and the country.

TK Al-Irsyad takes religious values as the basis of children's character building. Religious activities and traditions are strongly emphasized by the kindergarten in their educational activities. Religious values habituation and exemplification are significantly carried out in daily life. The approach taken in exemplification, according to (Legare, 2017), may become a way of instilling values, norms and standards into children's social interactions. The social skills applied in TK Al-Irsyad are effective, pursuant to Kemple, Lee, and Ellis's finding (2019) that children who participate in 
social skill programs show a significant increase in self-control and collaboration. The forms found are greeting children with friendly smiles and handshake when welcoming their arrival at school every morning and starting and ending learning activities in TK Al-Irsyad with praying. The other evident is the program of learning to read Qur'an (BTQ), celebration of Islamic holidays, and practice of daily worship. Certainly, it will be more prominent to instill and practice Islamic teachings on a daily basis. This is certainly related to its institutional status as an Islamic Kindergarten whose mission is to accustom children to living according to Islamic morality.

In addition to its orientation to children's character building, TK Al-Irsyad is also oriented to preparing children to enter further education. In doing so, the institution specifically provides children reading, writing and counting skills (calistung). The calistung training is based on pragmatic interest of meeting parents' demandthat their children will be able to read, write and count (calistung) when finishing kindergarten program. The parents' demand of Calistung abilities is also based on pragmatic reason that the will immediately participate in the lesson when entering primary school, some even expect their children to pass the entrance exam of certain primary schools with high number of applicants, in which calistung is one of the exams. This concept is in line with the one applied in Singaporean kindergartens, stating that Kindergarten curriculum is implemented to prepare children for entering elementary schools (Tan, 2017).

With regard to the demand for calistung abilities, there is an interesting fact that the principal views considering that calistung abilities demanded by the parents as something that should not yet be imposed to children since it is not 
appropriate for the stages of children's growth and learning style, and even if Calistung is taught, it should be performed with the concept of learning while playing.

In terms of educational services, TK Al-Irsyad emphasizes a creative-innovative concept, which is carried out by synergizing all potential resources, visionary leadership, adequate foundation's support, educators' creativity and performance, children integrated growth services, and developing adequate cooperation networks. Meeting children's needs is the top priority of all educational services provided.

In order to fulfill the integrative-holistic education system, TK Al-Irsyad implements an education system that unites educational services with nurturing, protection, health and nutrition with Islamic values as the basic principles. This system enables the children to grow up to their full potentials more optimally. Their physical and spiritual needs and development will be fulfilled through the integrative-holistic education system. Children's physical growth will later develop their understanding of the relationship between motion and health and make them appreciate physical activities (Brewer \& Renck, 2018; Nasiopoulou, 2019).

In case of grading system, TK Al-Irsyad uses authentic assessment, in which portfolio is one of the main assessment techniques. Portfolio in TK Al-Irsyad contains various data of children's learning progress (children's work: as a report form). These data are obtained from daily and informal activities as well as tasks. Portfolio is used to report children's and teachers' performances and evaluate children and teachers. Portfolios, prepared according to Gelfer and Perkins 
(1996), are used for children's progress report to parents and for demonstrating children's progress, as well as for reporting classroom activities.

\section{E. Conclusion}

Based on the findings above, TK Al Irsyad employs Smith system models developmentto apply Islamic teachingbased holistic-integrative approach. The approach applied is based on the concept and framework of systemic thinking in providing early childhood development services and is oriented to achieving good-quality output. This development occurs through a long process of structuring and implementation of an integrated education quality management. The process starts from strengthening input resources, raw input processing and transformation which involves good quality process elements, setting output targets with clear and measurable characteristics. Furthermore, the education system is implemented with an orientation to providing children with growth and development services in an integrative-holistic manner with the main orientation to character building and preparing them to enter further education level (SD/MI). The system is carried out by providing services in all aspects of children's growth and development, including care and protection, health and nutrition, and education services based on comprehensive playing activities. 


\section{REFERENCES}

Alhamuddin. (2018). Abd Shamad al-Palimbani's Islamic education concept: Analysis of Kitab Hidayah al-Sālikin fi Suluk Māsālāk lil Muttāqin. Qudus International Journal of Islamic Studies. https://doi.org/10.21043/ qijis.v6i1.3717.

Bredekamp, S., \& Copple, C. (2009). Developmentally Appropriate Practice in Early Childhood Programs Serving Children from Birth through Age 8. Young Children.

Brewer, H., \& Renck, M. (2018). Physical Activity and Health Promotion in the Early Years: Effective Strategies for Early Childhood Educators. In Educating the Young Child Advances in Theory and Research, Implications for Practice. https://doi.org/10.1007/978-3-319-760063.

Demina, D., Effendi, Z. M., Ananda, A., \& Damansyah, D. (2019). Application of Integrated Learning Model on Islamic Education in Improving Students Self Control in Madrasah Ibtidaiyah. https://doi.org/10.2991/ icoie-18.2019.16.

Dodge, D. T., Colker, L. J., \& Heroman, C. (2010). The Creative Curriculum for Preschool. Strategies.

Fonsén, E., \& Soukainen, U. (2019). Sustainable Pedagogical Leadershipin Finnish Early Childhood Education(ECE): An Evaluation by ECE Professionals. Early Childhood Education Journal. https://doi.org/10.1007/s10643019-00984-y.

Gelfer, J. I., \& Perkins, P. G. (1996). A model for portfolio assessment in early childhood education programs. Early Childhood Education Journal. https://doi. org/10.1007/BF02430543. 
Gestwicki, C. (2013). What is family Involvement? In Home, school, and community relations.

Janta, B., van Belle, J., \& Stewart, K. (2016). Quality and impact of Centre-based Early Childhood Education and Care. In Quality and impact of Centre-based Early Childhood Education and Care. https://doi.org/10.7249/rr1670.

Kemple, K. M., Lee, I., \& Ellis, S. M. (2019). The Impact of a Primary Prevention Program on Preschool Children's Social-Emotional Competence. Early Childhood Education Journal. https://doi.org/10.1007/s10643019-00963-3.

Legare, C. H. (2017). Cumulative cultural learning: Development and diversity. Proceedings of the National Academy of Sciences of the United States of America. https://doi.org/10.1073/pnas.1620743114.

Mayring, P. (2014). Qualitative content analysis: Theoretical foundation, basic procedures and software solution (free download via Social Science Open Access Repository SSOAR). Forum Qualitative Sozialforschung/ Forum: Qualitative Social Research.

Moleong, L. J. (2017). Metodologi Penelitian Kualitatif (Edisi Revisi). In PT. Remaja Rosda Karya.

Nasiopoulou, P. (2019). Investigating Swedish Preschool Teachers' Intentions Involved in Grouping Practices. Early Childhood Education Journal. https://doi. org/10.1007/s10643-019-00988-8.

Nengsi, A. W. (2019). Analisis Problematika Anak Usia 3-5 Tahun Belum Mendapatkan Pendidikan di Paud. Al Fitrah: Journal of Early Childhood Islamic Education. https://doi.org/10.29300/alfitrah.v2i2.2273.

Patmonodewo, S. (2003). Pendidikan Anak Prasekolah [Pra school of Child education]. Jakarta: Rineka Cipta. 
PERMENDIKNAS. (2009). Peraturan Menteri Pendidikan Nasional Republik Indonesia Nomor 58 Tahun 2009 tentang Standar Pendidikan Anak Usia Dini. https:// doi.org/10.2174/138920312803582960.

Pianta, R., Downer, J., \& Hamre, B. (2016). Quality in early education classrooms: Definitions, gaps, and systems. Future of Children. https://doi.org/10.1353/ foc. 2016.0015 .

Saipudin, A. (2010). Problematika Pendidikan AnakUsia Dini di Indonesia. Cakrawala Dini -Jurnal Pendidikan Anak Usia Dini. https://doi.org/10.17509/cd.v4i1.10371409.

Shoval, E., Sharir, T., Arnon, M., \& Tenenbaum, G. (2018). The Effect of Integrating Movement into the Learning Environment of Kindergarten Children on their Academic Achievements. Early Childhood Education Journal. https://doi.org/10.1007/s10643-0170870-x.

Suyanto, S. (2005). Dasar-Dasar Pendidikan Anak Usia Dini [Basics of Early Childhood Education]. Yogyakarta: Hikayat Publishing.

Tan, C. T. (2017). Enhancing the quality of kindergarten education in Singapore: policies and strategies in the 21st century. International Journal of Child Care and Education Policy. https://doi.org/10.1186/s40723017-0033-y.

Tunas, B. (2007). Memahami dan Memecahkan Masalah dengan Pendekatan Sistem. Jakarta: Nimas Multima.

Yus, A. (2011). Model Pendidikan Anak Usia Dini [Early Childhood Education Model]. Jakarta: Kencana. 